\title{
PEMANTAUAN INTAKE OUTPUT CAIRAN PADA PASIEN GAGAL GINJAL KRONIK DAPAT MENCEGAH OVERLOAD CAIRAN
}

\author{
Fany Angraini ${ }^{1 *}$, Arcellia Farosyah Putri ${ }^{1}$
}

1. Fakultas Ilmu Keperawatan Universitas Indonesia, Depok 16424, Indonesia

*Email: fany.angraini@ui.ac.id

\begin{abstract}
Abstrak
Pola diet tidak sehat pada masyarakat perkotaan merupakan salah satu faktor risiko penyakit tidak menular DM dan Hipertensi. Kedua penyakit tersebut menjadi dua penyebab utama kerusakan pada ginjal yang dapat berlanjut kepada tahap gagal ginjal (GGK). Pasien GGK seringkali mengalami masalah overload cairan yang dapat menimbulkan masalah kesehatan lainnya bahkan dapat berujung dengan kematian. Oleh karena itu, dibutuhkan program pembatasan cairan yang efektif dan efisien untuk mencegah komplikasi tersebut, diantaranya melalui upaya pemantauan intake output cairan. Penulisan karya ilmiah ini menggunakan metode studi kasus dengan tujuan menggambarkan metode pemantauan intake output cairan pasien GGK dengan menggunakan fluid intake output chart. Pemantauan tersebut terbukti efektif untuk menangani overload cairan pada klien, dibuktikan dengan berkurangnya manifestasi overload cairan pada klien.
\end{abstract}

Kata kunci: DM, fluid intake output chart, GGK, hipertensi, masyarakat perkotaan, overload cairan, pemantauan intake output cairan, pola diet yang tidak sehat

\section{Abstract}

Fluid Intake Output Monitoring of Chronic Renal Failure Patients can Prevent Fluid Overload. Unhealthy diet in urban society as one of risk factor noncommunicable disease, such as Diabetes and Hypertension. Both of them is leading causes of kidney disease and it can be End Stage Renal Disease stage (ESRS). ESRD patient often experience fluid overload state, that can cause another health problem even it can be cause of death. That's way, it is important to make effective and efficient fluid restriction program to prevent the complication, one other thing is fluid intake output monitoring. This scientific paper use case study method to describe analysis of clinical practice in fluid intake output monitoring by using fluid intake output chart. Monitoring is proven effective to treat fluid overload, it is shown by decreasing of patient's fluid overload clinical manifestation

Keyword: diabetes, ESRD, fluid intake output chart, fluid intake output monitoring, Fluid Overload, hypertension, unhealthy diet, urban society

\section{Pendahuluan}

Pola diet yang tidak sehat pada masyarakat perkotaan identik dengan konsumsi makanan siap saji ataupun makanan instan merupakan faktor risiko pemicu terjadinya penyakit tidak menular (PTM) seperti Hipertensi dan Diabetes Mellitus (DM) (WHO, 2008 dalam Kemenkes, 2011). Kedua penyakit tersebut menjadi dua penyebab utama terjadinya kerusakan ginjal yang dapat berlanjut kepada tahap gagal ginjal kronik (GGK) (Jha, Garcia,
Iseki, Li, Platner, Saran Wang, Yang, 2013 dan Caturdevy, 2014). Kegagalan fungsi ginjal dapat menimbulkan komplikasi gangguan kesehatan lainnya, salah satunya adalah kondisi overload cairan yang merupakan faktor pemicu terjadinya gangguan kardiovaskuler bahkan kematian yang terjadi pada pasien GGK (Angelantonio, Chowdhury, Sarwar, Aspelund, Danesh, \& Gudnason, 2010 dan Caturvedy, 2014). Meiliana (2013) menyatakan bahwa 54\% pasien yang menjalani HD di ruang HD RSUP Fatmawati memiliki riwayat 
overload cairan. Sementara itu, Wizemann (1995 dalam Tsai, Chen, Chiu, Kuo, Hwang, \& Hung 2014) menyatakan lebih dari $15 \%$ kasus overload menyebabkan kematian pada pasien yang menjalani hemodialisis. Komplikasi GGK sehubungan dengan overload dapat dicegah melalui pembatasan intake cairan yang efektif dan efisien.

Keefektifan pembatasan jumlah cairan pada pasien GGK bergantung kepada beberapa hal, antara lain pengetahuan pasien terhadap jumlah cairan yang boleh diminum. Upaya untuk mencipta-kan pembatasan asupan cairan pada pasien GGK diantaranya dapat dilakukan melalui pemantauan intake output cairan per harinya, sehubungan dengan intake cairan pasien GGK bergantung pada jumlah urin 24 jam (Europe-an Society for Parenteral and Enteral Nutri-tion dalam Pasticci, Fantuzzi, Pegoraro, Mc Cann, Bedogni, 2012).

Pemantauan dilakukan dengan cara mencatat jumlah cairan yang diminum dan jumlah urin setiap harinya pada chart/tabel (Shepherd, 2011). Sehubungan dengan pentingnya program pembatasan cairan pada pasien dalam rangka mencegah komplikasi serta mempertahankan kualitas hidup, maka perlu dilakukan analisis praktek terkait intervensi dalam mengontrol jumlah asupan cairan melalui pencatatan jumlah cairan yang diminum serta urin yang dikeluarkan setiap harinya.

\section{Metode}

Penulisan karya ilmiah ini menggunakan metode studi kasus, yaitu pasien dengan gagal ginjal kronik. Adapun teknik pengumpulan data yang digunakan meliputi wawancara, observasi partisipan, catatan individu, atau rekam medik dan perawatan. Data yang telah terkumpul dianalisis untuk melihat masalah keperawatan yang dialami klien serta meninjau keefektifan intervensi yang telah dilakukan untuk menyelesaikan masalah keperawatan pasien, khususnya masalah kelebihan volume cairan.

\section{Hasil}

Pasien yang menjadi kelolaan pada studi kasus ini adalah Ny. S (50 tahun), dirawat di RS sejak tanggal 7 Mei 2014 dengan keluhan ketika masuk, meliputi sesak nafas, kondisi kaki bengkak dan perut yang membesar, mual, serta lemas. Klien memiliki riwayat obesitas (riwayat $\mathrm{BB}=100 \mathrm{~kg}$, suka makan gorengan dan makanan berpenyedap kuat), riwayat merokok dan menderita DM tipe 2 (riwayat GDS 300 $\mathrm{mg} / \mathrm{dl}$ ) sejak empat tahun yang lalu disertai dengan hipertensi grade 1 (riwayat TD 160/90 $\mathrm{mmHg}$ ).

Masalah keperawatan yang muncul berdasarkan hasil pengkajian melalui anamnesa, pemeriksaan fisik dan pemeriksaan laboratorium, meliputi gangguan perfusi jaringan perifer, kelebihan volume cairan, risiko gangguan keseimbangan nutrisi, risiko infeksi, intoleransi aktivitas, serta kerusakan intergritas kulit.

Gangguan Perfusi Jaringan Perifer. Berdasarkan hasil pengkajian didapatkan data berupa tampilan klien yang tampak pucat, konjungtiva anemis, punggung kuku pucat, CRT memanjang (>3 detik), serta nilai $\mathrm{Hb}$ yang menurun $(5,7 \mathrm{gr} / \mathrm{dl})$.

Kelebihan Volume Cairan. Kelebihan volume cairan ditunjukkan dengan adanya data meliputi keluhan klien yang mengalami penurunan frekuensi BAK (2-3 kali/hari), jumlah urin sedikit, data observasi berupa adanya edema pitiing grade 3 pada kedua tungkai bawah klien serta ascites, jumlah urin dalam 24 jam (400 cc), tekanan darah 130/90 mmHg.

Risiko Gangguan Nutrisi. Sehubungan dengan masalah risiko gangguan nutrisi, adanya risiko ditunjukkan dengan ada-nya data berupa keluhan tidak nafsu makan, mual dan muntah, hasil observasi/pemeriksaan fisik dan laboratorium (porsi makan hanya $1 / 4$ bagian yang habis, $\mathrm{BB}=81 \mathrm{~kg}$, TB $170 \mathrm{~cm}$, postur tinggi sedang, $\mathrm{Hb}=5,7 \mathrm{gr} / \mathrm{dl}$, Albu-min=2,9 $\mathrm{gr} / \mathrm{dl}, \mathrm{LILA}=31 \mathrm{~cm}$, status gizi $=$ normal $)$. 
Risiko Infeksi. Masalah keperawatan risiko infeksi ditunjang dengan adanya data klien dengan riwayat penyakit kronik CKD semenjak 4 bulan yang lalu, hasil pemeriksaan terlihat kulit klien kering dan meneglupas (Xerotic Skin), kadar Ureum meningkat (161 $\mathrm{mg} / \mathrm{dl})$, penurunan kadar $\mathrm{Hb}(5,7 \mathrm{gr} / \mathrm{dl})$, penurunan kadar limfosit (limfosit 4). Keadaan tersebut meningkatkan risiko klien untuk terkena infeksi.

Kerusakan Integritas Kulit. Kondisi kulit klien dan peningkatan kadar ureum seperti yang sudah diuraikan sebelumnya, juga menjadi data penunjang munculnya masalah kerusakan integritas kulit. Data tambahan terkait kerusakan integritas kulit lainnya adalah berupa keluhan klien mengenai rasa gatal pada kulit.

Intoleransi Aktivitas. Intoleransi aktivitas dibuktikan dengan adanya data berupa keluhan lemas dari klien dan berdasarkan observasi klien tampak lemah, bed rest dan pemenuhan ADL dibantu keluarga.

Adapun tindakan keperawatan yang telah dilakukan selama pemberian asuhan keperawatan kepada Ny. S meliputi pemantauan status mental/ neurologis, pemantauan tanda-tanda vital, pemantauan status hidrasi (pemantauan BB, JVP, edema, ascites, intake output), pemantauan toleransi klien dalam melakukan ADL, pemberian motivasi kepada klien untuk meningkatkan intake makanannya, pemberian saran kepada klien untuk makan dengan porsi kecil tapi sering, pemberian kesehatan tentang diet rendah garam dan rendah protein, pendidikan kesehatan tentang hand hygiene, pemberian lotion pelembab untuk mengatasi kulit klien yang kering, kolaborasi pembatasan intake cairan, kolaborasi pemberian diet, kolaborasi pemantauan hasil laboratorium $(\mathrm{Hb}, \mathrm{Ur}, \& \mathrm{Cr})$, kolaborasi pemberian diuretik, antiemetik, antibiotik, antipruritus, serta transfusi PRC, kolaborasi pemberian tindakan HD.
Sehubungan dengan evaluasi tindakan keperawatan yang telah dilakukan didapatkan hasil sebagai berikut:

a. Masalah keperawatan gangguan perfusi jaringan perifer teratasi penuh pada hari rawat ke-3, setelah klien mendapatkan transfusi PRC ke 4. Hal tersebut ditandai dengan peningkatan kadar $\mathrm{Hb}(8,3 \mathrm{gr} / \mathrm{dl})$ dan berkurangnya anemis pada konjungtiva dan punggung kuku serta CRT $<3$ dtk. Meskipun demikian, pada hari terakhir klien dirawat, kadar $\mathrm{Hb}$ klien kembali mengalami penurunan $(\mathrm{Hb} 7,3 \mathrm{gr} / \mathrm{dl})$, klien direncanakan transfusi on HD pada jadwal HD berikutnya.

b. Masalah keperawatan kelebihan volume cairan mulai teratasi pada hari rawat ke-2, ditandai dengan penurunan derajat edema (edema grade 2), ascites berkurang, tidak ada penambahan BB dari hari sebelumnya, JVP tidak meningkat, balance cairan negatif, TD stabil $(130 / 90 \mathrm{mmHg})$ dan status mental CM. Masalah teratasi penuh pada hari terakhir klien dirawat ditunjukkan dengan penurunan derajat edema (derajat 1), ascites berkurang, tidak ada penambahan BB dari hari sebelumnya, JVP tidak meningkat, balance cairan negatif, suaran nafas vesikuler, status mental CM, dan TD stabil (130/90 mmHg).

c. Masalah risiko gangguan keseimbangan nutrisi mulai teratasi pada hari rawat ke-3, ditandai dengan keluhan mual yang dirasakan klien berkurang, porsi makanan yang habis bertambah ( $1 / 2$ porsi), nafsu makan mulai membaik. Masalah teratasi penuh pada hari teakhir klien dirawat, ditandai dengan hilangnya keluhan mual, nafsu makan membaik, porsi makanan yang habis $>50 \%$ (3/4 porsi).

d. Masalah risiko infeksi mulai teratasi pada hari pertama pemberian asuhan keperawatan pada klien, ditandai dengan tidak ada tanda infeksi. Masalah teratasi penuh pada 
hari terkahir perawatan klien ditandai dengan tidak adanya tanda infeksi pada klien serta kadar ureum darah klien yang sudah menurun $(90 \mathrm{mg} / \mathrm{dl})$.

e. Masalah kerusakan integritas kulit mulai teratasi pada hari rawat pertama ditandai dengan berkurangnya keluhan gatal pada kulit. Masalah teratasi penuh pada hari terakhir klien dirawat, ditunjukkan rasa gatal pada kulit. Masalah teratasi penuh pada hari terakhir klien dirawat, ditunjukkan dengan rasa gatal pada kulit berkurang, kulit sudah tidak terlalu kering dan mengelupas, kadar ureum darah menurun $(90 \mathrm{mg} / \mathrm{dl})$.

f. Masalah intoleransi aktivitas mulai teratasi pada hari rawat ke-4 ditandai dengan berkurangnya keluhan lemas yang dirasakan klien. Masalah teratasi penuh pada hari rawat terakhir, klien sudah mampu mobilisasi ke kamar mandi, karena badannya sudah tidak terlalu lemas.

\section{Pembahasan}

Pola diet yang tidak sehat pada masyarakat perkotaan meningkatkan risiko masyarakat perkotaan untuk terkena PTM, seperti Diabetes Mellitus (DM) dan Hipertensi (Kemenkes, 2011). Kedua penyakit tersebut menjadi dua penyebab utama terjadinya kerusakan ginjal yang dapat berlanjut kepada tahap gagal ginjal kronik (GGK) (Jha, Garcia, Iseki, Li, Platner, Saran Wang, Yang, 2013; Caturdevy, 2014).

Berdasarkan hasil observasi yang dilakukan di ruang rawat penyakit dalam menunjukkan sebanyak $50 \%$ pasien yang dirawat adalah pasien GGK. Tiga puluh lima persen penderita juga menderita DM dan hipertensi dengan riwayat kebiasaan makan yang tidak sehat.

Pola diet yang tidak sehat menjadi faktor pemicu awal gangguan ginjal yang dialami Ny.S. Berdasarkan hasil wawancara dengan pasien, didapatkan bahwa klien sering mengkonsumsi gorengan yang dibeli di pinggir ja- lan, makanan berpenyedap rasa yang kuat dan rutin mengkonsumsi kopi setiap harinya. $\mathrm{Pa}$ sien tersebut memiliki riwayat obesitas, dengan beratnya pernah mencapai $100 \mathrm{~kg}$, riwayat DM dan hipertensi semenjak 4 tahun yang lalu. Dapat disimpulkan DM dan menjadi faktor pemicu GGK pada Ny. S.

Gangguan Perfusi Jaringan Perifer. Kondisi anemia (Hb 5,7 gr/dl) merupakan manifestasi klinis lainnya yang dialami Ny. S. Kondisi tersebut berhubungan dengan kerusakan ginjal yang mengakibatkan penurunan fungsi ginjal dalam mensintesis enzim eritropoetin yang merupakan prekusor pembentukan sel darah merah pada sumsum tulang belakang. Selain itu, keadaan anemia pada Ny. S diperparah dengan deplesi komponen sel darah merah sehubungan dengan uremia (Ureum $161 \mathrm{mg} /$ dl). Uremia memberikan dampak buruk berupa hemolisis/pemendekan usia sel darah merah yang normalnya berusia 120 hari (LeMone \& Burke, 2008).

Penurunan kadar Hb kurang dari 6 gr/dl dapat mempengaruhi perfusi jaringan, sehingga berdasakan data tersebut memunculkan masalah keperawatan gangguan perfusi jaringan perifer (Doengoes \& Moorhouse, 2010).

Kelebihan Volume Cairan. Manifestasi klinis overload cairan yang dialami $\mathrm{Ny}$. S berupa edema grade 3 dan ascites berhubungan dengan penurunan kemampuan ginjal dalam meregulasi penyerapan dan haluaran elektrolit $\mathrm{Na}$, sehingga menyebabkan retensi $\mathrm{Na}$ yang lebih lanjut meningkatkan volume cairan ekstrasel. Keadaan overload pada Ny. S diperparah dengan adanya penurunan Laju Filtrasi Glomerulus/ LFG (LFG 8,7 ml/mnt), sehubungan dengan gangguan regulasi air oleh ginjal (Black \& Hawk, 2009).

Tindakan keperawatan dalam mengatasi overload meliputi pemantauan TTV (TD), status mental, CVP, distensi vena leher, suara nafas, berat badan, status hidrasi, pemantauan adanya edema, ascites, kolaborasi pembatasan cairan 
dan pantau intake output (Dongoes, Moorhouse, \& Murr, 2010).

Pemantauan tekanan darah menjadi salah satu intervensi utama dalam penanganan klien dengan overload karena TD merupakan salah satu indikator adanya peningkatan volume cairan intravaskuler. Peningkatan volume cairan berlebih pada kompartemen intarvaskuler lebih lanjut akan menyebabkan perpindahan cairan dari dalam pembuluh darah menuju jaringan interstisial tubuh. Oleh sebab itu, intervensi pemantauan TD pada pasien GGK sangat penting untuk memperkirakan kemungkinan terjadinya overload pada pasien (Black \& Hawk, 2009).

Intervensi berupa pemantauan status mental pada pasien GGK merupakan hal yang penting karena salah satu kemungkinan penyebab perubahan status mental pada pasien GGK adalah perpindahan cairan dari pembuluh darah otak menuju jaringan interstisial (edema serebral). Meskipun perubahan status mental pada pasien GGK lebih sering disebabkan karena akumulasi ureum dalam darah, namun akumulasi cairan pada jaringan otak dapat diprediksi menjadi kemungkinan penyebab lainnya (Ignatavicius \& Workman, 2010).

Pemantauan selanjutnya adalah berupa pemantauan adanya distensi vena jugularis dan mengukur JVP. Hal tersebut dapat dilakukan sehubungan dengan anatomi pembuluh darah tersebut bermuara pada vena sentral (vena cava superior). Peningkatan pada vena sentral sehubungan dengan meningkatnya volume sirkulasi sistemik akan berdampak kepada peningkatan JVP yang dapat terlihat dengan adanya distensi vena leher, jadi secara tidak langsung terhadap distensi vena leher dan peningkatan JVP menunjukkan kemungkinan adanya kondisi overload cairan (Smeltzer, Bare, Hinkle \& Ceever, 2010).

Intervensi berupa pemeriksaan fisik (auskultasi paru) penting dilakukan, sehubungan dengan adanya suara nafas abnormal crackle jika terdapat kelebihan cairan di rongga alveolus. Akumulasi tersebut terjadi karena perpindahan cairan dari kompartemen intravaskuler ke dalam rongga alveolus sehubungan dengan terjadinya peningkatan tekanan hidrostatik yang dihasilkan jantung karena adanya peningkatan volume cairan di dalam pembuluh darah. Akumulasi cairan tersebut dapat menimbulkan komplikasi gagal nafas.

Intervensi selanjutnya yang dilakukan dalam mengatasi kelebihan cairan pada pasien GGK adalah berupa pemantauan berat badan, edema atau ascites dan status hidrasi. Perubahan berat badan secara signifikan yang terjadi dalam 24 jam menjadi salah satu indikator status cairan dalam tubuh. Kenaikan $1 \mathrm{~kg}$ dalam 24 jam menunjukkan kemungkinan adanya tambahan akumulasi cairan pada jaringan tubuh sebanyak 1 liter. Pemantauan selanjutnya, berupa pemantauan adanya edema dan ascites menunjukkan adanya akumulasi cairan di jaringan interstisial tubuh yang salah satu kemungkinan penyebabnya perpindahan cairan ke jaringan. Salah satu pemicu kondisi tersebut adalah peningkatan volume cairan dalam pembuluh darah (Lewis, Heitkemper, Dirksen, O'Brien \& Bucher, 2007).

Sehubungan dengan tindakan kolaborasi, intervensi keperawatan dalam menangani kelebihan cairan diantaranya adalah kolaborasi pembatasan intake cairan. Pada pasien GGK pembatasan cairan harus dilakukan untuk menyesuaikan asupan cairan dengan toleransi ginjal dalam regulasi (ekresi cairan), hal tersebut dikarenakan penurunan laju ekresi ginjal dalam membuang kelebihan cairan tubuh sehubungan dengan penurunan LFG. Pada pasien ginjal intake cairan yang direkomendasikan bergantung pada jumlah urin 24 jam, yaitu jumlah urin 24 jam sebelumnya ditambahkan 500-800 cc (IWL) (Europan Society for Parenteral and Enteral Nutrition dalam Pasticci, Fantuzzi, Pegoraro, Mc Cann, Bedogni, 2012).

Pemantauan status hidrasi pada pasien GGK meliputi pemantauan intake output cairan sela- 
ma 24 jam dengan menggunakan chart intake output cairan untuk kemudian dilakukan penghitungan balance cairan (balance positif menunjukkan keadaan overload). Chart pemantauan intake output cairan klien, tidak hanya diisi oleh mahasiswa saja, namun juga diisi oleh klien. Hal tersebut bertujuan untuk melatih klien dalam memantau asupan dan haluaran cairan, sehingga pada saat pulang ke rumah klien sudah memiliki keterampilan berupa modifikasi perilaku khususnya dalam manajemen cairan. Keterampilan tersebut diharapkan dapat mencegah terjadinya overload cairan pada klien, mengingat jumlah asupan cairan klien bergantung kepada jumlah urin 24 jam.
Pada tahap awal dalam memberikan intervensi mahasiswa terlebih dahulu memperkenalkan chart meliputi nama serta tujuan pengisian chart. Setelah itu mahasiswa mulai memperkenalkan cara pengisian chart kepada klien. Pada dasarnya klien ataupun keluarga tidak memahami cara pengisian chart, karena cara pengisian yang cukup mudah seperti membuat catatan harian.

Berdasarkan catatan perkembangan penggunaan chart dalam rangka memantau intake output cairan, terlihat bahwa upaya yang dilakukan mahasiswa dalam manajemen kelebihan cairan cukup efektif, dibuktikan dengan jum-

Tabel 1 Chart Pemantauan Intake Output Cairan Klien

\begin{tabular}{|c|c|c|c|c|c|c|}
\hline \multicolumn{3}{|l|}{ Tanggal: } & \multicolumn{4}{|c|}{ Berat Badan: } \\
\hline \multirow[b]{2}{*}{ Waktu (WIB) } & \multicolumn{2}{|c|}{ Cairan masuk (ml) } & \multicolumn{4}{|c|}{ Cairan keluar (ml) } \\
\hline & Minum & Makanan & Muntah & Urin & BAB & Keterangan \\
\hline \multicolumn{7}{|l|}{01.00} \\
\hline \multicolumn{7}{|l|}{02.00} \\
\hline \multicolumn{7}{|l|}{03.00} \\
\hline \multicolumn{7}{|l|}{04.00} \\
\hline \multicolumn{7}{|l|}{05.00} \\
\hline \multicolumn{7}{|l|}{06.00} \\
\hline \multicolumn{7}{|l|}{07.00} \\
\hline \multicolumn{7}{|l|}{ SUB TOTAL } \\
\hline \multicolumn{7}{|l|}{08.00} \\
\hline \multicolumn{7}{|l|}{09.00} \\
\hline \multicolumn{7}{|l|}{10.00} \\
\hline \multicolumn{7}{|l|}{11.00} \\
\hline \multicolumn{7}{|l|}{12.00} \\
\hline \multicolumn{7}{|l|}{13.00} \\
\hline \multicolumn{7}{|l|}{14.00} \\
\hline \multicolumn{7}{|l|}{ SUB TOTAL } \\
\hline \multicolumn{7}{|l|}{15.00} \\
\hline \multicolumn{7}{|l|}{16.00} \\
\hline \multicolumn{7}{|l|}{17.00} \\
\hline \multicolumn{7}{|l|}{18.00} \\
\hline \multicolumn{7}{|l|}{19.00} \\
\hline \multicolumn{7}{|l|}{20.00} \\
\hline \multicolumn{7}{|l|}{21.00} \\
\hline \multicolumn{7}{|l|}{22.00} \\
\hline \multicolumn{7}{|l|}{23.00} \\
\hline 24.00 & & & & & & \\
\hline SUB TOTAL & & & & & & \\
\hline TOTAL /24 jam & & & & & & \\
\hline
\end{tabular}

Dimodifikasi dari Fluid Balance Record ( www.dxmedicalstationery.com.au) 
lah intake cairan klien terkontrol sesuai dengan haluaran urin, berkurangnya kelebihan cairan yang dialami klien dibuktikan dengan tidak ada peningkatan BB yang meningkat signifikan setiap harinya, edema/ascites berkurang, tekanan darah stabil, suara nafas vesikuler, status mental CM, tidak ada distensi vena leher (JVP tidak meningkat), serta balance cairan yang negatif. Pelaksanaan asuhan keperawatan yang dilakukan mahasiswa selama praktek tidak lepas dari kendala, diantaranya terkait sarana.

Adapun sarana yang dimaksud adalah belum tersedianya gelas ukur urin dan formulir khusus pemantauan intake output cairan khususnya untuk pasien GGK di ruang rawat, padahal kedua komponen tersebut merupakan bagian dari standar operasional prosedur pemantauan intake output cairan dengan menggunakan intake output cairan (Sephard, 2010). Untuk menangani masalah tersebut, mahasiswa mencoba mencari alternatif, berupa penggantian gelas ukur urin dengan menggunakan tampung berupa botol air mineral bekas dan menggunakan formulir pemantauan intake output yang diterjemahkan dan diadaptasi dari luar negeri (Bennet, 2010 dalam Shepherd, 2011).

Kendala yang ditemui selama penelitian tidak hanya berhubungan dengan sarana saja, tetapi juga berhubungan dengan kerja sama klien atau keluarga dalam memberikan informasi intake output cairan yang benar. Klien atau keluarga terkadang lupa untuk mengukur intake cairan maupun haluaran urin, sehingga dapat memengaruhi keakuratan data intake output cairan klien karena pencatatan jumlah cairan melalui perkiraan saja dan bukan melalui pengukuran. Kendala tersebut tidak berlangsung lama dan terjadi di awal pemberian asuhan keperawatan, setelah diberikan edukasi dan diingatkan secara berulang-ulang, akhirnya kepatuhan klien/keluarga mengalami peningkatan. Hal tersebut dibuktikan dengan kerutinan mencatat setiap intake dan output pada intake output chart yang juga diberikan pada klien.

Risiko Gangguan Nutrisi. Keluhan klien berupa mual, penurunan nafsu makan terjadi sehubungan dengan uremia $(161 \mathrm{mg} / \mathrm{dl})$. Peningkatan ureum yang merupakan sampah sisa metabolisme protein dan semestinya dibuang dari dalam tubuh terjadi karena penurunan fungsi klirens ginjal sehubungan dengan penurunan LFG. Pada Ny. S, berdasarkan formula kreatinin klirens didapatkan LFG klien hanya $8,7 \mathrm{ml} / \mathrm{mnt}$.

Risiko Infeksi. Peningkatan kadar ureum juga menyebabkan gangguan pada fungsi leukosit sebagai agen yang berperan dalam sisitem imun. Pada klien terjadi penurunan kadar Limfosit, hal tersebut menempatkan klien pada risiko infeksi.

Kerusakan Integritas Kulit. Keluhan klien berupa rasa gatal pada kulit dan kondisi kulit yang kering/bersisik dan mengelupas merupakan manifestasi klinis dari keadaan uremia yang dialami klien.

Intoleransi Aktivitas. Penurunan kadar $\mathrm{Hb}$ yang menyebabkan kondisi anemia pada klien menimbulkan manifestasi klinis berupa badan yang terasa lemas, kepala pusing, sehinggan membuat klien tidak mampu melakukan aktivitas untuk pemenuhan ADL.

\section{Kesimpulan}

Penyakit tidak menular yang sering ditemukan di perkotaan adalah DM dan hipertensi yang disebabkan oleh pola diet yang tidak sehat misalnya konsumsi makaan siap saji yang mengandung kadar kolesterol, gula dan garam yang tinggi. DM dan hipertensi lebih lanjut menyebabkan komplikasi gangguan kesehatan berupa GGK yang menyebabkan gangguan regulasi cairan dan elektrolit dan memicu terjadinya kondisi overload cairan pada penderita. 
Overload cairan lebih lanjut dapat menimbulkan komplikasi berupa gagal jantung, edema paru yang dapat berujung kematian. Oleh sebab itu, dibutuhkan manajemen cairan berupa pembatasan cairan efektif dan efisien untuk mencegah kompilkasi tersebut. Upaya untuk menciptakan program pembatasan cairan yang efektif dan efisien, salah satunya dapat dilakukan melalui pemantauan intake output cairan pasien selama 24 jam dengan menggunakan fluid intake output chart.

Sehubungan dengan pentingnya upaya pemantauan intake output cairan pada pasien GGK, maka rumah sakit perlu menyediakan alat ukur urin serta formulir pemantauan intake output cairan yang sudah terstandarisasi tidak hanya di ruang perawatan kritis saja. Hal tersebut diperlukan untuk memfasilitasi perawat dalam memberikan intervensi keperawatan berupa pemantauan intake output yang akurat, sehingga komplikasi overload cairan pada pasien GGK dapat diminimalisasi (US, $\mathrm{TN})$.

\section{Referensi}

Angelantonio, E. D., Chowdhury, R., Sarwar, N., Aspelund, T., Danesh, J., \& Gudnason, V. (2010). Chronic kidney disease and risk of major cardiovascular disease and nonvascular mortality: prospective population based cohort study. British medical journal $341,768$.

Black, J. M. \& Hawks, J. H. (2009). Medicalsurgical nursing: Clinical management for positive outcomes (8th Ed.). St. Louis: Saunders Elsevier.

Caturvedy, M. (2014). Management of hypertension in CKD. Clinical queries: nephrology 3, 1-4.

Dx Medical Stationery. 2013. Fluid balance record data form. Diperoleh dari http://dxmedicalstati onery.com.au.
Dongoes, M.E., Moorhouse, M.F., \& Murr, A.C. (2010). Nursing care plans:guideline for individualizing client care across the life span (8th Ed.). Philadelphia: F. A Davis Company

Ignatavicius, D. D., \& Workman, M. L. (2010). Medical-surgical nursing: Patient-centered collaboraive care. (6th ed). St. Louis: Sauders Elsevier.

Jha, V., Garcia-Garcia, G., Iseki, K., Li, Z., Naicker, S., Plattner, B., Saran, R., Wang, A.Y., \& Yang, C.W. (2013). Chronic kidney disease: global dimnesion and perspectives. Lancet, 382 (9888), 260-272. doi: 10. 1016/S0140-6736(13)60687-X

Kementerian Kesehatan RI. (2011). Stategi nasional penerapan pola konsumsi dan aktifitas fisik untuk mencegah penyakit tidak menular. Jakarta: Kementerian Kesehatan Republik Indonesia.

Meiliana, R. (2013). Hubungan kepatuhan terhadap terjadinya overload pada pasien gagal ginjal kronik post hemodialisa di Rumah Sakit Fatmawati (Skripsi, tidak dipublikasikan). Program Studi Sarjana Fakultas Ilmu Keperawatan, Universitas Indonesia, Depok - Jawa Barat, Indonesia.

Pasticci, F., Fantuzzi, A. L., Pegoraro M., Mc Cann, M., \& Bedogni, G. (2012). Nutritional management stage 5 of chronic kidney disease. Journal of renal care, 38 (1), 50-58. doi: 10.1111/j.1755-6686.2012.00266.x

Shepherd, A. (2011) Measuring and managing fluid balance. Nursing times 107(28), 12-16. Diperoleh dari https://www.ncbi.nlm. nih.gov/p ubmed/21941718

Tsai, Y. C., Tsai, J. C., Chen, S. C., Chiu, Y. W., Hwang, S. Y., Hung, C. C., Chen, T. H., Kuo, M. C., \& Chen, H. C. (2014). Association of fluid overload with kidney disease progression in advanced CKD: a rospective cohort study. American of Journal 
Kidney Disease, 63 (1), 68-75. doi: 10.1053/j.ajkd.2013.06.011

Western Health and Social Care Trust. (2010). Policy for he recording of fluid balancel intake-output. Diperoleh dari http://www. nmc-uk.org 